\title{
Introduction: the anthropology of corruption
}

\section{Davide Torsello}

Apart from the early work of James Scott (1972), the word "corruption" has been until recent years almost absent from the anthropological literature. It is only after 1995 that corruption becomes present on a highly irregular basis in journal articles. The World Bank has funded a large research project to highlight the most important disciplinary contributions to the field (2006). The result of this extensive literature review is the relative "silence" of anthropology regarding corruption. The sum of anthropological studies dealing with this phenomenon covers only about $2 \%$ of the relevant scientific literature. In spite of this, the recent developments point to a growing interest within anthropology in the topic of corruption (mostly in politics, with some minor exceptions for business). Nonetheless, a survey of the literature conducted by the author in 2013 has identified more than 260 academic articles and books published in English, French, Spanish and Italian over the last two decades.

The reasons for this "silence" could be divided between methodological, ethical and epistemic concerns. From the methodological point of view, anthropology has discovered the most visible manifestations of corruption but has decided to remain rather silent on their wider effects (Zinn 2001). Anthropology's earlier accounts of gift-exchange processes, reciprocity, redistribution, informal economic transactions, moral economy, clientelism, nepotism, cronyism and social networks are some of the topics in which the discipline was the pioneer rather than the latecomer. The lack of research on corruption could be explained by a feeling of responsibility on the misuse of some of the ethnographic findings, which have contributed, in science as in politics, to cultural essentializations as well as to increasing the ideological gap between a "modern," "rational" and "transparent" west and a "traditional," "irrational" and "corrupt" rest. Anthropologists have then found themselves under a paradoxical injunction regarding fieldwork leading to the discovery of corruption practices. On an ethical and deontological level, the ethnographer cannot put into danger the people under observation. Since the ethnographer in the course of his/her observation 
will study the various behaviors, interactions, thoughts and symbols associated to corruption, he/she will potentially gather enough data to put his/ her respondents into a risky position.

On an epistemic level, corruption is commonly defined as the misuse of public power for private benefits. For anthropology, this well-accepted definition is very problematic since it is based partly on a strong private-public dichotomy. Anthropological studies have raised abundant evidence to the point where the opposition of public-private is context dependent. In the anthropologic epistemology, the truth of a social reality can be discovered primarily when the scientist gives voice to the observed. Thus, through the everyday reality of their functioning, institutions are not abstract entities, as they are made up of people, and through their agencies, narratives, ideas and ideologies. Hence, anthropology cannot agree with a definition stating a neat distinction between private and public roles, tasks and aims. Rather than accepting the public/private dichotomy, anthropologists dealing with corruption stress the different ways in which variant actors conceive, contest and operationalize it.

\section{THE STATE, GOVERNMENTALITY AND CORRUPTION}

Anthropology has provided sophisticated ethnographies of the state in relation to a number of political and social phenomena and cultural practices (Sharma and Gupta 2006). Following the influence of Foucauldian interests with regard to issues of power, knowledge, discourses and governmentality, ethnographic accounts of the role of the state in relation to corruption have taken different standpoints. These can be summarized in three perspectives: normative, hermeneutical and transactional (or social exchange theory), and will be treated in detail below.

By highlighting the diversity of social norms' function in and within societies, anthropology has built a strong critique of the western dichotomy of state/society and developed a dual perspective of the role of the state. The state is portrayed either as a weak enforcing actor of anticorruption norms and laws or as a legislative agent of ad hoc norms to increase unaccountability.

In one of the most recent contributions to this approach, Nuijten and Anders (2007) have emphasized the idea that the common western-centric notion of corruption, grounded on the dichotomy between public and private interests, is of little help to anthropological investigations. They depart from the legal anthropological perspective that looks at law as plural, and profoundly influenced by social processes (Moore 2000). 
Corruption and law are not opposite, but constitutive of one another, just as legal prescription and its transgressions are not mutually exclusive. Because the possibility of transgression is always present in law, corruption is to these authors the very "secret of law," which defines fields of law's application and intervention, but meanwhile allows for its transgression in society. An approach that looks at law as the only cure against corruption, individuating in the state the main actor of law-making, is misleading because law is plural. Therefore, it is only through empirical sensibility for its pluralism that corruption can be successfully detected through its nuances as an alternative form of legal order (MacNaughton and Wong 2007; Znoj 2007).

Pardo (2004) makes a similar point but from a different angle. For him, the political and legal conceptualization of corruption and of its effects within the state boundaries are marked by inherent ambiguities. Pardo, who conducted fieldwork in southern Italy, recognizes that anthropology is confronted with the difficult balance of historical and ethnographic variations and universal aspects. He understands that one of the main limits of the anthropology of corruption has been its cultural particularism, and proposes two roads to overcome this impasse. The first is to look at morality as a conflicting battlefield in which socially constructed ideas of legality and illegality collide with universal claims of legitimacy. The second is to investigate the role of the state which can be both above the corrupt game, and part of it, participating in law-making. The state may even legitimize the ambitions of those corrupt politicians, who, claiming to re-attribute morality to political action, eventually make use of law-making to render more opaque the borders of legality and illegality. In this perspective, the state is an active participant in the process of setting the agenda for corruption and not a passive agent fighting against its effects. Law creates the sphere of legitimacy through which corruption is accepted or rejected, conceived of and exploited by those in power.

In the hermeneutical approach focus is on the sphere of governmentality rather than governance, individuating ground-level efforts to interpret political power. Corruption is one of the ways in which people make sense of politics and of the state, like a conversation, a ritual or for some even like witchcraft (Bähre 2005; Bubandt 2006; Rudnyckyj 2009). The focus of analysis should not be whether the state has been able to set the boundaries between legality and illegality, morality and immorality, or whether the state makes use of corruption to obtain legitimacy. Anthropologists have here introduced the innovative focus on the discursive practices of corruption to understand its role in governance.

The third approach is the transactional approach, or social exchange theory. Corruption is analyzed here as a mechanism of interaction 
between different levels of political decision-making. A number of ethnographic studies have showed that corruption exemplifies a failure of the state to encompass local government, or an incomplete bureaucratization process (Prato 2004; Zerilli 2005; De Vries 2007). Competition between local governments and the state becomes one potential subject of analysis in reference to different socio-cultural contexts, for instance in China (Smart and Hsu 2007), Indonesia (Bähre 2005; Bubandt 2006), Latin America (Lomnitz 1995; Goldstein 2003). For example, in his study about the effects of European Union (EU) structural transport projects in Central Eastern Europe, Torsello (2012) has been confronted with the issue of whether corruption has been fostered by the attempt of the state to enforce its decision-making processes at local levels, or by the opposite, by the attempt of localities to seek autonomy from state intervention. $\mathrm{He}$ has found that one fruitful way to analyze the spreading of corruption in relation to EU enlargement politics is through attention to competition between state and local governments over EU funds. After experiencing a profound process of institutional transformation, Eastern Europe has entered a similarly problematic phase of alignment with EU accession requirements, and afterwards structural development policies. Corruption is a mechanism that not simply allows the classical "greasing of the wheel," but it generates conflicting dynamics of interaction and transaction between national, local and transnational governing agents. Some of these dynamics may have seemingly positive outcomes (such as building an infrastructure or ameliorating an urban space), but in most cases the loss of legitimacy of each of the political actors implicated in these transactions occurs under the watchful eyes of the general public.

\section{THE NORMATIVE APPROACH}

Many social scientists from the west have criticized the immorality of corruption in developing countries by taking an overtly superior stance. A clear example of moralization can be seen in the work of some economists on the link between corruption and economic development. In his oftencited article, Mauro (1995) suggests that corruption lowers investment, and consequently economic growth. Anthropologists could interpret this thesis as judgmental because it suggests that developing countries are poor because they are dishonest. Anthropologists are very concerned by the dichotomy between economic development and level of corruption. There is an underlying idea of superiority between a "modern," "rational," and "transparent" west and a "traditional," "irrational," and "corrupt" rest. Anthropologists reject the moral dualism of corruption, according to 
which the decision to engage in corruption is bad and the refusal to do so is good. Rather than this Manichean view of corruption, anthropologists favor a nuanced approach by analyzing corruption from the point of view of the people concerned.

Although most social scientists agree on the damage that corruption can cause, the moralization of the debate can be problematic for scientific inquiry (Leff 1964; Leys 1965; Nye 1967). Indeed, Leff (1964) has argued that the widespread condemnation of corruption constitutes a major obstacle to research because it hinders an objective examination of the concept.

The issue of morality in relation to public officers who seek to serve their own interests through bribes, gifts, and favors is the subject of extensive debate in the ethnographic literature on corruption. Anthropologists do not see morality as a homogeneous and universal phenomenon. This contrasts with the classical approach of western political philosophy, which, drawing on Aristotelian traditions, sees moral integrity at the core of the development of accountable, rational and democratic forms of governance (Rothstein and Eek 2009). Anthropological accounts of social morality draw more on its etymology, from the Latin mores, which means "social customs."

Anthropology provides a fresh approach to the moral aspects of corruption. The causal relationships that some scholars have identified between morality and economic development, social trust, social capital and civil society (Banfield 1958; Fukuyama 1995; Putnam 1993, 2000) have provoked major debates in anthropology, sociology and political science (Silverman 1965; Miller 1974; Muraskin 1974; Tarrow 1996; Meloni, 1997).

However, if ethos were the only explanation for problematic socioeconomic phenomena such as clientelism and corruption, there would be little need for ethnographic and empirical works on these issues. These works would be expected to generate data confirming the origin and resilience of social practices such as familism, individualism, collectivism and Protestant versus Catholic values. Nevertheless, many ethnographic works have produced empirical data that not only challenge these assumptions, but that also weaken the moral order approach (Pardo 2004).

One problem with approaches focusing on the moral aspects of corruption is that these moral aspects tend to be socially and culturally specific. The moral order approach alone is not sufficient to understand corruption. For example, the role of the state, the local tradition of social movements, the role of social networks in framing identity, and the role of informal networks and exchange practices all have different meanings in particular contexts. The importance given to moral dimension in the analysis of corruption leads researchers to forget that corruption practices are strongly 
embedded in ordinary forms of sociability, influenced by culture. Thus, in the case of China, Yang (2002) has drawn attention to how different cultural backgrounds at different points affect the practice of corruption.

Ethnographic studies of corruption contribute two original aspects to the debate on morality and corruption. The first is the notion that corrupt practices may not only be deemed as functional, but also as morally acceptable and even socially cohesive. In the case of India, for example, Visvanhatan contrasts the "warm nature of corruption" against the "cold of bureaucratic rationality" (2008). Dracklé also describes the case of Portugal, where corruption is driven by the conflicting claims and strategies of local agricultural entrepreneurs who spend much of their time attempting to gain access to "discreet bureaucrats" (2005). Investigating the case of China, Steinmüller (2010) describes the dichotomy, used by local scholars and intellectuals, between a modern, rational truth and a neo-traditionalist truth. However, he argues that the former often represents a façade of morality, because the bureaucratic sector is dominated by personal relationships and patronage. These relationships are rooted in Confucian ideals of connectivism, reciprocity and personal ties of obligation (Yang 2002; Smart and Hsu 2007). However, public discourses in China on morality are increasingly informed by western ideas of rationality that expressively portray "traditional" customs as forms of "state involution," which could lead to the coexistence of two conflicting sets of moralities on corruption.

One common ethnographic finding is that the diffusion of neoliberal values erodes and transforms the existing moral order to the point of transposing social values. This perspective therefore offers a dynamic approach to morality. For example, Rivkin-Fish studied corruption in the Russian healthcare system (2005) and found that, unlike corrupt practices under socialism that involved working "on the side" to fill gaps in the centrally planned economy, corruption in post-socialist Russia involves providing spaces for generating mutual trust (Rivkin-Fish 2005). The market economy has resulted in a diminished space for social interactions, and corruption is used to fill this gap. The gift and bribe system has also been strongly affected by the conspicuous introduction of money into these transactions in recent years. Local perceptions of what constitutes moral conduct are changing, and practices that were once socially acceptable in Russia are becoming ethically problematic as they come to involve money. As has been observed in several other ethnographic contexts, this trend reveals a new tension between (petty) corrupt practices that are viewed as socially acceptable and practices in which money and sudden gain become manifest, and which are therefore perceived as immoral.

In one of the most theory-oriented anthropological contributions 
to the study of corruption, Oliver de Sardan uses the notion of the "moral economy" to refer to the African case (1999). For him, the key to understanding the widespread diffusion of corruption in Africa is to consider its "banalization" and "generalization" in everyday practices and discourses. He sees corruption as a realm of rumor and gossip, where the political and the social become intermingled and semantically determined. As a result of a number of culturally constructed practices (gift-giving, brokerage, solidarity networks, predatory authority and redistributive accumulation), corruption becomes a commonly accepted practice.

Hasty (2005) makes a similar point in his study of anti-corruption officers in Ghana. During his fieldwork, Hasty had the advantage of being both a journalist and a trained anthropologist. His profession gave him access to individuals and documents that were inaccessible to other ethnographers. He describes the personal characteristics and actions of bureaucrats working in anti-corruption offices who strive to maintain self-discipline and integrity in spite of the many forms of "desire" that can drive corruption. Hasty describes officials who refused to take gifts of food and drink (except for soft drinks), despite this being extremely common in several African contexts. These officials are seen as retiring, antisocial and morally suspect by the local population. As a matter of fact, their behavior contrasts with locally accepted standards of morality, in which conviviality and participation in lavish banquets, among other practices, are seen as a natural and morally unproblematic aspect of material wealth and power.

In the case of Italy, Pardo (2004) and Miller (2004) underline how in southern Italy the use of money to pay for the services of public officials (such as Neapolitan doctors) leads to a delicate balance of long-term and short-term moral commitments. Miller is a magistrate with vast experience in Italian corruption cases. He suggests that the exchange of power for money is viewed as immoral conduct (2004). However, this immoral conduct could be classified into two types: short-term, which is merely instrumental, and long-term personal relationships, which are more morally acceptable (Miller 2004: 53-55). This is supported by findings in Eastern Europe (Humphrey and Sneath 2004; Rigi 2004). Describing the case of Latvia, Sedlenieks suggests that corruption becomes morally acceptable at a social level when there is extensive use of monetary remittances (2004). In Latvia, money is considered "fertile," and corruption is morally acceptable when it brings about long-lasting personal relations. Petty corruption can be more easily condemned and considered "barren money" when it benefits only the individual rather than the social community. Similar points are raised in Latin American contexts, such as Mexico and Colombia, where the public hope is that social benefits will arise from the political dynamics of corruption (Gledhill 2004; Lazar 2005). In all these cases, market 
values contrast and intertwine with existing moral orders, calling for new and often conflicting interpretations of what constitutes moral conduct in relation to corruption.

\section{THE HERMENEUTICAL PERSPECTIVE}

In contrast with the social norm approach, the hermeneutical perspective looks at the sphere of governmentality rather than governance, exploring ground-level efforts to interpret political power. Drawing from a rich theoretical background that originates in the works of Michel Foucault, Clifford Geertz, Victor Turner and, recently, John-Jean Comaroff and Michael Herzfeld, this perspective aims to detect the discursive function of corruption. Foucault coined the term "governmentality" (from the words "governing" and "mentality") to highlight the interdependence between the exercise of government and the mentalities that shape this exercise. Governmentality is a "guideline" for analyzing the links between forms of government and modes of thought about governing (Foucault 1991).

For anthropologists, the rhetoric of the elites and the general population on corruption is as interesting as its practice. A strong argument in favor of analyzing the discourse about corruption revolves around the fact that the perception of corruption is crucial for its understanding (Blundo 2007).

Following Foucault's work on the discursive expressions of power, anthropologists have studied the communicative aspects of corruption. Ethnographers have identified two contradictory effects of using the term "corruption" in the public domain. On the one hand, widespread public discourse about corruption may contribute to the strengthening of social ties of belonging, sharing and common identity. This may be accomplished when people join together to denounce corruption and the damage it can do to the social fabric of society. On the other hand, exposure to frequent public denouncements of corruption can increase cynicism and decrease trust in political institutions, as political scientists have demonstrated, for example, in the case of Russia (Venard 2009). While the second observation can be measured easily through quantitative methods, the first is harder to detect.

For anthropologists, corruption can become a "language" or a "meta-language" that is in everyday use, and public discussion of corruption provides opportunities for citizens to communicate anxieties, concerns and ideas about their society (Gupta 2005). From this perspective, the discourse about corruption can be seen as an attempt to control threats to social and normative orders (Parry 2001). Similarly, the above-mentioned sociability that ethnographers attribute to petty corruption and informal 
practices is observed in the case of widespread corruption talk (Gupta 1995; Corbin 2004; Humphrey and Sneath 2004; Znoj 2007). In some countries, people talk freely in public and abundantly about corruption. These dialogues show that corruption can be an opportunity for communication, whether in an open or a concealed manner. When the conversation is hidden, the very secrecy and conspiratorial nature of this practice adds to its communicative power and creates social differences between those unable to access information on corruption and those possessing such knowledge (Nuijten and Anders 2007).

Anthropologists have reported other cases in which the communicative power of corruption is part of a deliberate political strategy. In their study of anti-mafia movements in Palermo, Jane and Peter Schneider (2005) describe a case in which criminal activities and extortion were used as powerful cognitive schemas in which to frame the difficult consolidation of civic organizations. For some anti-mafia activists, discourses on criminal activities and corruption have a strong political significance in a region such as Sicily, where it is important to avoid speaking about it, in line with the dominant value of omertà (conspiracy of silence). Similarly, Torsello showed how, in the new EU member states of Central Eastern Europe, denouncing corruption was deployed as a (more or less) successful communicative strategy by environmentalist movements seeking to garner public participation in their protest campaigns against transport development projects (Torsello 2012). Initially, the communication of environmental movements used the preservation of nature as the main argument in their struggle against EU and state transport development projects. When the complex implementation of these projects resulted in corruption, some civic organizations quickly embraced this new discursive "weapon."

The importance given to discourse in anthropology is also understandable from a methodological point of view. Because corruption is very difficult to observe directly, informants are required to describe their experiences. When anthropologists interview protagonists of corruption practices they collect an interpretation by the informant regarding corruption. The informant recounts his or her experience and builds a discourse using his or her system of values and social norms. This discourse may range from a simple description to a more complex explanation, and even a complete justification.

Corruption is one of the ways in which people make sense of politics and the state. It is akin to a conversation, to a ritual, or for some, even to witchcraft. The comparison of corruption with witchcraft has been raised by a number of anthropologists (Bähre 2005; Bubandt 2006; Blundo 2007; Rudnyckyj 2009). There are two ideas underlining this association. The first is that corruption, like witchcraft, can be a way to re-establish a 
distorted moral and symbolic order, particularly in conditions of profound institutional transformation such as in post- or neo-colonial economies. The second refers to the secrecy of corruption practices, which, like sorcery, help users gain access to power and hence demystify the secrets through which state power functions. The focus of analysis should not be whether the state has been able to set the boundaries between legality and illegality or between morality and immorality, or whether the state uses corruption to obtain legitimacy. Instead, anthropologists in this field recommend focusing on the discursive practices of corruption to understand its role in governance.

This hermeneutic approach is present in the work of Gupta, who provides one of the most refined contributions to the anthropology of corruption (1995, 2005). Gupta describes how local citizens in India use corruption as a form of discourse to obtain information which will allow them to access otherwise inaccessible benefits. He identifies a political strategy devised by citizens, which involves seeking information on ways to bribe successfully, how much money is to be paid, and which interactional conditions require bribes to access state services. Gupta's work highlights the need to differentiate between two discursive uses of corruption in relation to governmentality. The first concerns the process of information seeking about whom, how, and when to bribe. The second corresponds to public discourse, i.e. the ways in which ordinary citizens address corruption in their everyday lives and how their denouncements influence social ties of trust and solidarity.

Gupta shows that the state connects with ordinary citizens via face-toface relations with local officers. These local officers are able to use clientelistic and personal networks to perpetuate their power. This situation contrasts with the general western view of the opposition between state and society. In the ethnographies on India, corruption is the space in which the state intertwines with social practices, relations and even moralities. In this approach, the state may appear much more disaggregated and decentralized than when viewed through the traditional lens. However, reference to corruption in public discourses, especially by politicians, brings the state back into play, as Bailey (1969) and Boissevain (1974) have shown. The discourse about corruption by politicians, NGO leaders and social activists could allow them to improve their public image and thus reinforce their power and influence (Scott 1972). Some ethnographic studies have stressed this point (Wade 1982; Kondos 1987; Price 1999; Ruud 2000, 2001; Sewanta 2009; Torsello 2012). For example, in an empirical study conducted in Nepal, Sewanta demonstrated how local citizens use corruption at a discursive level to differentiate between the performances and capacities of a number of institutions from the police force, to health, 
education and postal services (2009). Like Gupta, Sewanta suggests that this discursive use of corruption does not necessarily deter local citizens from engaging with state officials, but rather works as a frame of reference to establish effective practices under such conditions.

\section{THE SOCIAL EXCHANGE THEORY}

Due to the aforementioned methodological and ethical constraints, anthropology has not dealt expressively with all typologies of corruption, such as those including administrative, electoral and corporate corruption, as other disciplines do. Anthropology has so far mostly dealt with the difference in types of corruption departing from the distinction between petty and grand corruption. On the one hand, petty corruption is commonly the field which ethnographers can more effectively study when they are interested in the "morality" of mutual ties of reciprocity, gift exchange and interpersonal trust. On the other hand, grand corruption has mainly remained out of ethnographic investigations for methodological reasons, i.e. the difficulty of investigating ethnographically corporate and large political scandals.

Methodologically, the ethnographer often may be exposed to observation of gift-giving and informality in economic transactions, semi-legal or illegal practices, clientelism and bribery. Nevertheless, being in the troublesome position of judging whose goods are serving those practices, the common tendency of the ethnographer is to objectivize the meaning of those practices, framing them into the socio-cultural context of belonging, which leads to the above mentioned distaste for clear-cut categories. One example is Yang's work on guanxi (personal connections) in China (1994). These are practices substantiated through the widespread use of gift exchanges in interpersonal relations where favors are granted. Yang reflects on the inappropriate use that some scholars have made of her interpretation of such practices which she saw emerging in the times of the Cultural Revolution as a reaction to conditions of excessive state inherence in public life (2002). She is careful to treat guanxi not as a given set of cultural practices, but as a historically specific product acquiring different meanings and deployments along ethnic, class, gender and even regional dimensions. As a culturally recognized form of social exchange, guanxi and other similar practices observed in different world regions (Latin America, Southern and Eastern Europe, Africa) can be perceived as patterns of sociability that define ways for how different sets of actors can interact within and/or outside of schemes of state control and institutions. In the case of guanxi, connections are justified by the Confucian virtue 
of connectedness, according to which individuals are not single atomized beings, but social beings inserted in nested relations (from the family all the way up to the state), without which a person (contrary to the western philosophical tradition) is not characterizable, or, as the Japanese say, without which a person does not have a "social face" (hitomae). Some of these approaches in the anthropology of corruption have generated what can be called the "social exchange theory of corruption."

The problem with the social exchange theory is that it may lead to overemphasizing petty corruption practices and be less explanatory for larger phenomena, such as those in which multiple political and economic actors are involved. Some anthropologists (Parry 2001; Haller and Shore 2005) have warned that the social exchange theory applied to corruption may become misused to stigmatize socio-cultural practices which become attributed at aggregate level as characteristic of one single nation, or even of cultures.

Exchange patterns have, as Befu (1977) underlined, their context, rules and strategies which have both universal and relativistic features. This explains the need to provide a more dynamic and spatial-temporal informed view of corruption. From this perspective, the "morality" of corruption at local level resides in its being accepted, according to some particular conditions of political institutional and market development, as a common social form of exchange. This is not to argue that less wealthy or political unstable countries are more corrupt because they prefer "informal" or "gift-like" exchange relations that are embedded in society. Rather, the nature of reciprocity and exchange makes corruption a universal phenomenon since it is inserted in a mechanism of exchange in which power to influence the bribe taker is emphasized, and in which the socio-cultural conditions of the exchange determine the assessment of the value of the bribe and hence the significance of corruption (de Sardan 1999). This approach can provide an explanation to one of the most widely debated issues on the phenomenon: the dichotomy between its high socio-cultural variance in terms of causes in spite of the strong worldwide similarity of its consequences.

\section{ETHNOGRAPHIC RESEARCH ON CORRUPTION: METHODOLOGY ISSUES}

As mentioned above, corruption is a phenomenon that cannot be observed easily in everyday practices. As noticed in different fieldwork contexts, there may occur the emergence of two opposite situations: there is scarce observed evidence or discussion on corruption; or the studied social reality 
may deal excessively with corruption in public and private discourses. Both conditions are alterable due to the intrusive presence of the ethnographer, and particularly when he or she is of foreign nationality.

If participant observation is an insufficient methodology for studying corruption, the use of interviews is typically the best option. Interviews, conducted with single people, have the advantage of allowing the interviewee to interact alone with the researcher, leaving space for relatively less constrained flows of opinions and life views. Even though the performative effect of the interview may arise, the ethnographer still has the option to control this with a series of check questions. Moreover, when dealing with key personalities, such as public administrators, judges, company managers and journalists, structured and semi-structured interviews obviously become the only options for the collection of ethnographic data.

Another methodological tool which has been successfully applied in ethnographic contexts is the survey questionnaire. The questionnaire is not intended here as a statistical research device, but rather as a semiquantitative tool (sample sizes are usually not large) allowing the ethnographer to gather information from a number of interlocutors, not necessarily specialized, with whom he or she would not be able to interact. Of course the issue of addressing a whole questionnaire on the sensitive topic of corruption remains. Some successful attempts, however, have been dedicated to bridge the topic with others (social values, reciprocity, gift-exchange patterns, power, informality) that anthropological accounts have found in connection with corruption.

Finally, focus groups, a tool not completely familiar to anthropologists, may reveal precious instruments for data gathering. Focus groups, typically conducted with a small number of interlocutors who share similar degrees of knowledge and working experience with the topic, have two advantages. First, by bringing people together to converse freely on a selected and shared list of topics it is possible to observe not only their knowledge but also their participation dynamics in the group. Second, the nature of the interaction among the participants may reveal other aspects to interlocutors (their personal commitment, attachment to some particular values, cultural and cognitive approaches to the topic, power and relational aspects) that would otherwise be unnoticed in traditional interviews.

\section{CONCEPTUAL PROBLEMS}

One issue on which anthropological investigations tend to agree is the difficult and problematic conceptualization of the notion. Substantiated by ethnographic field research, several contributions have maintained that 
corruption has too often been accepted uncritically as a social phenomenon. This is not to state, as some other social scientists erroneously think, that anthropology's relativism has led scholars to accept corruption almost uncritically as a social and even cultural practice. Corruption is problematized more often by ethnographic contributions than by the quantitative and deductive methodologies' inspired literature. One example is the recent boom of indicators for measuring or assessing correlational measures of this and several other economic, political, social and cultural variables. The point is not only that anthropology can hardly provide a contribution to such debates, given its traditional preference for qualitative research, but that the conceptualization and in particular the definition of corruption which have been commonly developed within other disciplines have not been as universally accepted within anthropology.

First, the almost commonsensical definition of "abuse of public office for private gain" is problematic for anthropology for two reasons. The first is that the analytical circumscription of what "public office" and "private gain" mean is strongly informed by local ideas and practices, not to say culture (the number of anthropologists maintaining these points is too large to provide some meaningful references). It is not always clear that local citizens understand the difference between a state and a private doctor, a state and a private university professor, or a state-controlled company and a regular private enterprise. Conversely, as seen above concerning the normative approach, the ready-made definition of "private gain" often involves the researcher in an empirical riddle: should the private gain consist of material benefits shared among a corrupt politician, a company which gets a bid and gives work to 100 workers, and eventually a community of people who, willing or unwilling, get the construction of a bridge? Whose private gain is at stake? Is the anti-corruption argument still tenable whenever a local informant would maintain that "thanks to dirty money at least we have something done for us"? Isn't corruption a phenomenon that is increasingly difficult to eradicate particularly because the number of those who receive personal gains is increasing dramatically, and the "traditional" corruptor-corrupted dyadic relationship is becoming anacronstical?

Second, contrary to what non-anthropologists may think, providing a multifaceted definition of corruption is not reductive and relativistic. One of the strengths of the growing ethnographic literature is that it is able to provide a wider and more flexible spectrum of analysis than what has commonly been achieved so far. If corruption has increasingly become associated with other crimes, from white collar crimes to abuse of office, nepotism, clientelism or more generally favouritism, one needs a much more open definition of the phenomenon to describe what is going on 
worldwide. The idea that corruption changes its face and is extremely adaptive to transformation in macroeconomic and political terms has been accepted by experts and policy makers. Thus, why stick to a single definition if the phenomenon is in constant mutation?

Taking a holistic approach, ethnography has been open to capturing the complexity of corruption in ideas and practices on the ground, rather than looking for answers to pre-formed questions. This emerged not only from the differences among the analytical approaches illustrated above, but also from the reality of fieldwork research, which situates the ethnographer in a delicate and complex position in which observing corruption per se, within a strict definition, is a rare happening. Anthropological investigation of a "closed" organization such as a public administration is perhaps the best example of this sort of limitation. Not only is the ethnographer exposed to limited and cautious information from the interviewees, but he or she is in the position of having to judge which practice falls into the basket of corruption and which does not. This is because, as widely noticed, internationally corruption has become a catchphrase, an epitome of a number of practices that sometimes even the specialist observers do not know how to discern; not to mention the position of public officers who have received, in many of the countries studied in this volume, little or no training and education in integrity and transparency.

The third aspect concerns the typologies of corruption. There can be different types and forms of corruption according to the particular domains in which this illegal practice takes place: political, administrative, business or corporate, systemic and petty corruption. Of course, the analytical benefits of this distinction are clear. On an empirical basis, however, the difficulty of gaining a clear picture of the persistency of this phenomenon and of its legitimacy at local level creates for the researcher barriers that are sometimes insurmountable.

One of the outcomes of a questionnaire survey conducted with common citizens in the countries that are the object of investigation in this book has been that respondents seem biased differently towards some types of corruption that they, in general, denounced very strongly, and less concerned by others that perhaps could not be considered as "particuarly noxious." Whereas political and administrative corruption was widely denounced for instance, both business and petty corruption were not put under the same spotlight. One possible reason for this could be that business corruption, with its complex human and organizational logics and impenetrability, is poorly understood by many citizens. On the other hand, however, petty corruption was seen, surprisingly, as less detrimental to society at large, not because of the small nature of the bribes at stake, but because it came to be seen as a form of social exchange, as suggested above. 
As underlined above, ethnographic studies of corruption have dealt mostly with petty corruption, as this is typically the type of corruption about which information is more easily collectable. Most of the anthropology works on corruption informed by the observation of local practices focus on small payments made to different types of public officers (the police, doctors and nurses, educators, tax and custom officers, local government officials, and so on). These are the only practices that can be observed or encountered relatively easily during fieldwork (de Sardan 1999).

The study of all the other forms of corruption is a different endeavor, which requires a different methodology and which has to take other approaches. If an ethnographer would rarely encounter a case of political, administrative or business corruption personally, it is still possible to focus on public discourses, legal procedural transcriptions and media coverage of cases and scandals. In such cases, the emphasis of the research would not be on the social mechanisms through which corruption takes place but on the wider interaction of different spheres (economic, political, legal, social and cultural), the symbolic reconstruction of this interaction, and the significance that such interaction expressed in the criminal act has for a society as a whole, as the hermeneutical approach demonstrates. Ethnography is, here, less the observation of practices which is, for the deontological and epistemological reasons expressed above, highly problematic, and more the cultural analysis of a text, be it the transcript of a magistrate's court hearing, a newspaper article or an interview with a public officer.

The ethnographic study of corruption, in any organizational and institutional context, has as its main task the analysis of the mechanisms that bind together actions, discourses, symbols, metaphors and any sociocultural forms of expression through which this phenomenon takes place, is accepted or rejected. It cannot be a moral(istic) endeavor since the ethnographer cannot judge; like a journalist he or she aims to report faithfully what he or she sees, hears and reads. Unlike a journalist, he or she goes beyond words and images, and attempts to catch the invisible threads or webs of the spider that spins what Geertz (1973) called culture, but not only in the search for meanings and symbols. The ethnography of corruption potentially has the, original, strength of connecting symbols and meanings with the forms and mechanisms of social interaction. In this it provides a unique contribution to the study of corruption - although this has been neglected so far - i.e. the ability to conceive of this notion as immersed in the reality of the everyday, rather than abstracted through models that are often far from this reality, making the eradication of corruption a chimeric effort. 


\section{BIBLIOGRAPHY}

Bähre, E. (2005). How to ignore corruption. Reporting the shortcomings of development in Africa. Current Anthropology, 46(1): 107-113.

Bailey, F. (1969). Stratagems and Spoils. New York: Shocken Books.

Banfield, E. (1958). The Moral Basis of a Backward Society. New York: Free Press.

Bardhan, P. (1997). Corruption and development: a review of issues. Journal of Economic Literature, 35: 1329.

Becker, H. (1963). Outsiders: Studies in the Sociology of Deviance. New York: The Free Press.

Beets, D. (2005). Understanding the demand-side issues of international corruption. Journal of Business Ethics, 57: 65-81.

Befu, H. (1977). Social exchange. Annual Review of Anthropology, 6: 255-281.

Bierstaker, J. (2009). Differences in attitude about fraud and corruption across cultures. Cross Cultural Management, 16(3): 241-250.

Blundo, G. (2006). Dealing with the local state: the informal privatization of streetlevel bureaucracies in Senegal. Development and Change, 37(4): 799-819.

Blundo, G. (2007). Hidden acts. Open talks. How anthropology can "observe" and describe corruption. In Nuijtel, M. and Anders, G. (eds.) Corruption and the Secret of Law: A Legal Anthropological Perspective. Aldershot: Ashgate, 1-17.

Boas, F. (1887). Museums of ethnology and their classification. Science, 9: 589.

Boissevain, J. (1974). Friends of Friends: Networks, Manipulators and Coalitions. Oxford: Blackwell.

Bourgois, P. (1995/2003). In Search of Respect: Selling Crack in El Barrio. Structural Analysis in the Social Sciences Series. New York and Cambridge: Cambridge University Press.

Bourgois, P. and Schonberg, J. (2009). Righteous Dopefiend. Public Anthropology Series. Berkeley: University of California Press.

Brief, A., Buttram, R. and Dukerich, J. (2001). Collective corruption in the corporate world: toward a process model. In Turner, M. E. (ed.) Groups at Work: Advances in Theory and Research. Hillsdale, NJ: Lawrence Erlbaum, 471-499.

Brouthers, L., Gao, Y. and McNicol, J. (2008). Corruption and market attractiveness influences on different types of FDI. Strategic Management Journal, 29: 673-680.

Bubandt, N. (2006). Sorcery, corruption and the dangers of democracy in Indonesia. Journal of the Royal Anthropological Institute (New Series), 12: 413-431.

Chapman, M. (2001). Social anthroplogy and business studies: some considerations of method. In Gellner, D. N. and Hirsch, E. (eds.) Inside Organizations: Anthropologists at Work. Oxford: Berg, 19-33.

Clifford, J. and Marcus, G. E. (eds.) (1986). Writing Culture. The Poetics and Politics of Ethnography. Berkeley: University of California Press.

Collins, J., Uhlenbruck, K. and Rodriguez, P. (2008). Why firms engage in corruption: a top management perspective. Journal of Business Ethics, 87: 89-108.

Corbin, J. (2004). Interés, morality and legality in southern Spain. In Pardo, I (ed.) Between Morality and the Law. Corruption, Anthropology and Comparative Society. London: Ashgate, 19-32.

Cuervo-Cazurra, A. (2006). Who cares about corruption? Journal of International Business Studies, 37: 807-822.

Cuervo-Cazurra, A. (2008). Better the devil you don't know: types of corruption 
and FDI in transition economies. Journal of International Management, 14: $12-27$.

D'Iribarne, P., Segal, J. P., Chevrier, S. and Globokar, T. (1998). Cultures et Mondialisation. Gérer par-delà les frontières. Paris: Seuil.

Dalakoglou, D. (2010). Migrating-remitting-'building'-dwelling: house-making as 'proxy' presence in postsocialist Albania. Journal of the Royal Anthropological Institute, 16: 761-777.

Davis, J. and Ruhe, J. (2003). Perceptions of country corruption: antecedents and outcomes. Journal of Business Ethics, 43(4): 275-288.

de Sardan, O. (1999). A moral economy of corruption in Africa? The Journal of Modern African Studies, 37(1): 25-52.

De Soto, H. (1990). The Other Path: The Invisible Revolution in the Third World. New York: Harper.

De Vries, P. (2007). The orchestration of corruption and excessive enjoyment in western Mexico. In Nuijtel, M. and Anders, G. (ed.) Corruption and the Secret of Law: A Legal Anthropological Perspective. Aldershot: Ashgate, 143-166.

Della Porta, D. and Vannucci, A. (1999). Corrupt Exchanges. Actors, Resources, and Mechanisms of Political Corruption. New York: de Gruyter.

Doig, A. and Theobald, R. (ed.) (2000). Corruption and Democratisation. London, Portland, OR: Frank Cass.

Douglas, M. (1966). Purity and Danger. On the Analysis of the Concepts of Pollution and Taboo. London: Kegan and Paul.

Douglas, M. (1970). Natural Symbols: Explorations in Cosmology. London: Penguin Books.

Douglas, M. (1978). Cultural Bias. London: Royal Anthropological Institute.

Dracklé, D. (2005). Where the jeep comes from: narratives of corruption in the Alentejo (southern Portugal). In Haller, D. and Shore, C. (eds.) Corruption: Anthropological Perspectives. London: Pluto, 194-211.

Durkheim, E. (1950). The Rules of Sociological Method. Glencoe, IL: The Free Press.

Evans-Pritchard, E. (1937/1963). Witchcraft, Oracles, and Magic among the Azande. Oxford: Clarendon Press.

Everett, J., Neu, D. and Rahaman, A. (2006). The global fight against corruption: a foucaultian, virtues-ethics framing. Journal of Business Ethics, 65: 1-12.

Fleming, P. and Zyglidopoulos, S. C. (2008). The escalation of deception in organizations. Journal of Business Ethics, 81: 837-850.

Foucault, M. (1991). Governmentality. In Burchell, G., Gordon, C. and Miller, P. (eds.) The Foucault Effect: Studies in Governmentality. Hemel Hempstead: Harvester Wheatsheaf, 87-104.

Foucault, M. (2007). Security, Territory, Population: Lectures at the Collège de France, 1977-1978, trans. G. Burchell. Basingstoke and New York: Palgrave Macmillan.

Fukuyama, F. (1995). Trust. The Social Virtues and the Creation of Prosperity. New York: Free Press.

Galang, R. (2012). Victim or victimizer. Firm responses to government corruption. Journal of Management Studies, 49(2): 429-462.

Geertz, C. (1973). The Interpretation of Cultures: Selected Essays. New York: Basic Books.

Gioia, D. (1992). Pinto fires and personal ethics. Journal of Business Ethics, 11: 379-389. 
Gledhill, J. (2004). Corruption as the mirror of the state in Latin America. In Pardo, I. (ed.) Between Morality and the Law. Corruption, Anthropology and Comparative Society. London: Ashgate, 155-180.

Goldstein, L. (2003). "In our own hands": lynching, justice and the law in Bolivia. American Ethnologist, 30(1): 22-43.

Gordon, K. and Miyake, M. (2001). Business approaches to combating bribery: a study of code of conduct. Journal of Business Ethics, 34(3-4): 161-173.

Greve, H., Palmer, D. and Pozner, J. O. (2010). Organizations gone wild: the causes, processes and consequences of organizational misconduct. The Academy of Management Annals, 4(1): 53-107.

Gupta, A. (1995). Blurred boundaries: the discourses of corruption, the culture of politics and the imagined state. American Ethnologist, 22(2): 375-402.

Gupta, A. (2005). Narratives of corruption: anthropological and fictional accounts of the Indian state. Ethnography, 6(1): 5-34.

Habib, M. and Zurawicki, L. (2002). Corruption and foreign direct investment. Journal of International Business Studies, 33(2): 291-307.

Haller, D. and Shore, C. (2005). Introduction. Sharp practice: anthropology and the study of corruption. In Haller, D. and Shore, C. (eds.). Corruption: Anthropological Perspectives. London: Pluto, 1-28.

Harrison, E. (2010). Unpacking the anti-corruption agenda: dilemmas for anthropologists. Oxford Development Studies, 34(1): 15-29.

Hasty, J. (2005). The pleasures of corruption. Desire and discipline in Ghanaian political culture. Cultural Anthropology, 20(2): 271-301.

Headland, T., Pike, K. and Harris, M. (eds.) (1990). Emics and Etics: The Insider/ Outsider Debate. Frontiers of anthropology. Newbury Park, CA: Sage.

Heidenheimer, A. and Johnson, M. (1989/2011). Political Corruption: A Handbook. New Brunswick, NJ: Transaction Books.

Hoag, C. (2010). The magic of the populace: an ethnography of illegibility in the South Africa immigration bureaucracy. Political and Legal Anthropology Review, 33(1): 6-25.

Hooker, J. (2009). Corruption from a cross-cultural perspective. Cross-cultural Management, 16(3): 251-267.

Hsu, C. and Smart, A. (2007). Corruption or social capital? Tact and performance of guanxi in market socialist China. In Nuijtel, M. and Anders, G. (eds.) Corruption and the Secret of Law: a Legal Anthropological Perspective. Aldershot: Ashgate, 167-190.

Humphrey, C. and Sneath, D. (2004). Shanghaied by the bureaucracy. Bribery and post-Soviet officialdom in Russia and Mongolia. In Pardo, I. (ed.) Between Morality and the Law. Corruption, Anthropology and Comparative Society. London: Ashgate, 85-100.

Huntington, S. (1968). Political Order in Changing Societies. New Haven, CT: Yale University Press.

Jain, A. (ed.) (1998). Economics of Corruption. Dordrecht: Kluwer.

Jain, A. (2001). Corruption: a review. Journal of Economic Surveys, 15(1): 71-121.

Johnston, M. (2005). Syndromes of Corruption: Wealth, Power, and Democracy. Cambridge: Cambridge University Press.

Kondos, A. (1987). The question of "corruption" in Nepal. Mankind, 17(1): 15-29.

Lazar, S. (2005). Citizens despite the state: everyday corruption and local politics in En Alto, Bolivia. In D. Haller and C. Shore (eds.) Corruption: Anthropological Perspectives, London: Pluto Press, 212-228. 
Leff, N.H. (1964). Economic development through bureaucratic corruption. American Behavioral Scientist, 8(3): 8-14.

Leys, C. (1965). What is the problem about corruption? Journal of Modern African Studies, 3(2): 215-230.

Lomnitz, L. (1995). Ritual, rumor and corruption in the constitution of polity in modern Mexico. Journal of Latin American Anthropology, 1(1): 20-47.

Lovett, S., Simmons, L. and Kali, R. (1999). Guanxi versus the market: ethics and efficiency. Journal of International Business Studies, 30(2): 231-247.

Lui, F. T. (1985). An equilibrium queuing model of bribery. Journal of Political Economy, 93(4): 760-781.

MacNaughton, E. and Wong, K. (2007). Corruption judgements in pre-war Japan: locating the influence of tradition, morality and trust on criminal justice. In Nuijtel, M. and Anders, G. (eds.) Corruption and the Secret of Law: a Legal Anthropological Perspective. Aldershot: Ashgate, 77-98.

Mauro, P. (1995). Corruption and growth. Quarterly Journal of Economics, 110(3): 681-712.

Mauss, M. (1923/2005). The Gift: The Form and Reason for Exchange in Archaic Societies. Milton Park: Routledge (Classics).

Meloni, B. (ed.) (1997). Famiglia meridionale senza familismo. Strategie economiche, reti di relazione e parentela. Catanzaro: Meridiana.

Miller, A. (2004). Corruption between morality and legitimacy in the context of globalization. In Pardo, I. (ed.) Between Morality and the Law. Corruption, Anthropology and Comparative Society. London: Ashgate, 53-68.

Miller, R. (1974). Are familists amoral? A test of Banfield's amoral familism hypothesis in a south Italian village. American Ethnologist, 1(3): $515-535$.

Montinola, G. and Jackman, R. (2002). Sources of corruption: a cross-national study. British Journal of Political Science, 32: 147-170.

Moore, S. (2000). Law as Social Process. Hamburg: LIT.

Muraskin, W. (1974). Review: the moral basis of a backward sociologist. Edward Banfield, the Italians and the Italian-Americans. American Journal of Sociology, 79(6): 1484-1496.

Nuijten, M. and Anders, G. (eds.) (2007). Corruption and the Secret of Law: a Legal Anthropological Perspective. Aldershot: Ashgate.

Nye, J.S. (1967). Corruption and political development: a cost-benefit analysis. The American Political Science Review, 61(2): 417-427.

Pardo, I. (ed.) (2004). Between Morality and the Law. Corruption, Anthropology and Comparative Society. London: Ashgate.

Parry, J. (2001). The crisis of corruption and the idea of India - a worm's eye view. In Pardo, I. (ed.) Morals of Legitimacy: Between Agency and System. Oxford: Bergahn Books, 27-56.

Plattner, S. (1989). Economic Anthropology. Stanford: Stanford University Press.

Prato, G. (2004). The devil is not as wicked as people believe, neither is the Albanian. Corruption between moral discourses and national identity. In Pardo, I. (ed.) Between Morality and the Law. Corruption, Anthropology and Comparative Society. London: Ashgate, 69-84.

Price, P. (1999). Cosmologies and corruption in (South) India. Forum for Development Studies, 2: 315-327.

Putnam, R. (1993). Making Democracy Work. Civic Traditions in Modern Italy. Princeton: Princeton University Press. 
Putnam, R. (2000). Bowling Alone. The Collapse and Revival of American Community. New York: Simon and Schuster.

Rigi, J. (2004). Corruption in post-Soviet Kazhakstan. In Pardo, I. (ed.) Between Morality and the Law. Corruption, Anthropology and Comparative Society. London: Ashgate, 101-118.

Rivkin-Fish, M. (2005). Bribes, gifts and unofficial payments: re-thinking corruption in post-Soviet health care. In Haller, D. and Shore, C. (eds.) Corruption. Anthropological Perspectives. London: Pluto Press, 47-64.

Rose-Ackerman, S. (1999). Corruption and Government. Causes, Consequences, and Reform. Cambridge, New York: Cambridge University Press.

Rose-Ackerman, S. (ed.) (2006). International Handbook on the Economics of Corruption. Cheltenham, UK and Northampton, MA, USA: Edward Elgar.

Rothstein, B. and Eek, D. (2009). Political corruption and social trust. An experimental approach. Rationality and Society, 21(1): 81-112.

Rudnyckyj, D. (2009). Spiritual economies: Islam and neoliberalism in contemporary Indonesia. Cultural Anthropology, 24(1): 104-141.

Ruud, A. (2000). Corruption as everyday practice. The public-private divide in local Indian society. Forum for Development Studies, 2: 271-294.

Ruud, A. (2001). Talking dirty about politics. A view from a Bengali village. In Fuller, C. J. and Benei, V. (eds.) The Everyday State and Society in Modern India. London: C. Hurst and Co., 115-136.

Schneider, J. and Schneider, P. (2005). The sack of two cities: organized crime and political corruption in Youngstown and Palermo. In Haller, D. and Shore, C. (eds.) Corruption: Anthropological Perspectives. London: Pluto, 29-46.

Scott, J. (1972). Comparative Political Corruption. Englewood Cliffs, NJ: Prentice Hall.

Scott, S. (2010). Negotiating power: elections and the constitution of indigenous Taiwan. American Ethnologist, 37(4): 726-740.

Sedlenieks, K. (2004). Rotten talk: corruption as a part of discourse in contemporary Latvia. In Pardo, I. (ed.) Between Morality and the Law. Corruption, Anthropology and Comparative Society. London: Ashgate, 119-134.

Sewanta, K. (2009). Local level perception of corruption: an anthropological inquiry. Dhaulagiri Journal of Sociology and Anthropology, 3: 163-174.

Sharma, A. and Gupta, A. (eds.) (2006). The Anthropology of the State: A Reader. Malden, MA: Blackwell.

Shibutani, T. (1986). Social Processes. Berkeley: University of California Press.

Shleifer, A. and Vishny, R. (1993). Corruption. Quarterly Journal of Economics, August, 108(3): 599-617.

Silverman, S. (1965). Agricultural organization, social structure and values in Italy: amoral familism reconsidered. American Anthropologist, 70(1): 1-20.

Smart, A. and Hsu, C. (2007). Corruption or social capital? Tact and the performance of guanxi in market socialist China. In Nuijtel, M. and Anders, G. (eds.) Corruption and the Secret of Law: a Legal Anthropological Perspective. Aldershot: Ashgate, 167-190.

Steinmüller, H. (2010). Communities of complicity: notes on state formation and local sociality in rural China. American Ethnologist, 37(3): 539-549.

Steward, J. (1955/1990). Theory of Culture Change: The Methodology of Multilinear Evolution. Champaign: University of Illinois Press.

Tarrow, S. (1996). Make social science work across space and time: a critical 
reflection on Robert Putnam's Making Democracy Work. American Political Science Review, 90(2): 389-397.

Torsello, D. (2010). Corruption and the economic crisis: empirical indications from Eastern Europe. Slovak Foreign Policy Affairs, 19(2): 65-75.

Torsello, D. (2011). The ethnography of corruption: research themes in political anthropology. Working Paper 2011:2. Quality of Government Institute, University of Gothenburg.

Torsello, D. (2012). The New Environmentalism? Civil Society and Corruption in the Enlarged EU. Farnham: Ashgate.

Torsello, D. (2015). Corruption as social exchange: the view from anthropology. In Hardi, P., Heywood, P. M. and D. Torsello (eds.) Debates of Corruption and Integrity: Perspectives from Europe and the US. New York: Palgrave Macmillan, $159-183$.

Venard, B. (2009). Organizational isomorphism and corruption: An empirical research in Russia. Journal of Business Ethics, 89: 59-76.

Visvanhatan, S. (2008). The necessity of corruption. Accessed 3 October 2010 at http://www.india seminar.com/2008/590/590_shiv_visvanathan.htm.

Wade, R. (1982). The system of administrative and political corruption: Canal irrigation in South India. The Journal of Development Studies, 18(3): 287-327.

Wolcott, (1995/2005). The Art of Fieldwork. Washington, DC: Rowman Alta Mira Press.

World Bank (2006, 28 March). World Bank Literature Survey on Corruption; 2000-2005. Accessed 1 October 2010 at http://www1.worldbank.org/publicsector/anticorrupt/ACLitSurvey.pdf.

Xin, K. and Pearce, J. (1996). Guanxi, connections as substitute for formal institutional support. Academy of Management Journal, 39(6): 1641-1658.

Yang, M. (1994). Gifts, Favors and Banquets: The Art of Social Relationships in China. Ithaca: Cornell University Press.

Yang, M. (2002). The resilience of Guanxi and its new deployments: a critique of some new Guanxi scholarship. China Quarterly, 170: 459-476.

Zerilli, F. (2005). Corruption, property restitution and Romanianness. In Haller, D. and Shore, C. (ed.) Corruption: Anthropological Perspectives. London: Pluto, 83-102.

Zinn, D. (2001). La raccomandazione: clientelismo vecchio e nuovo. Roma: Donzelli.

Znoj, H. (2007). Deep corruption in Indonesia: discourses, practices, histories. In Nuijtel, M. and Anders, G. (eds.) Corruption and the Secret of Law: a Legal Anthropological Perspective. Aldershot: Ashgate, 53-76. 